PYTHAGORAS: Jurnal Pendidikan Matematika

Volume 11 - Nomor 1, Juni 2016, (59-68)

Available online at: http://journal.uny.ac.id/index.php/pythagoras

\title{
Pembelajaran Geometri Berbantuan Geogebra dan Cabri Ditinjau dari Prestasi Belajar, Berpikir Kreatif dan Self-Efficacy
}

\author{
Paulus Roy Saputra \\ Universitas Riau Kepulauan, Jalan Batu Aji Baru No.99, Kepulauan Riau, Indonesia \\ Korespondensi Penulis. Email: roysaputra21 @ gmail.com, Telp: +6285751959303 \\ Received: 15 $5^{\text {th }}$ June 2016; Revised: $25^{\text {th }}$ July 2016; Accepted: $1^{\text {st }}$ September 2016
}

\begin{abstract}
Abstrak
Penelitian ini bertujuan untuk mendeskripsikan dan membandingkan keefektifan pembelajaran geometri berbantuan Cabri dan pembelajaran geometri berbantuan Geogebra ditinjau dari prestasi belajar, berpikir kreatif, dan self-efficacy siswa SMP. Penelitian ini adalah penelitian eksperimen semu desain pretest-posttest non equivalent group design. Penelitian ini menggunakan dua kelompok eksperimen tanpa kelompok kontrol. Populasi penelitian ini mencakup seluruh siswa kelas VII SMP Santa Maria Banjarmasin. Sampel terdiri dari dua kelas, yaitu kelas $\mathrm{VII}_{\mathrm{A}}$ dan kelas $\mathrm{VII}_{\mathrm{B}}$ yang dipilih secara acak. Kelas $\mathrm{VII}_{\mathrm{A}}$ menggunakan pembelajaran geometri berbantuan Cabri dan kelas $\mathrm{VII}_{\mathrm{B}}$ menggunakan pembelajaran geometri berbantuan Geogebra. Hasil penelitian ini menunjukkan bahwa ditinjau dari prestasi belajar, berpikir kreatif, dan self-efficacy siswa (1) pembelajaran geometri berbantuan Cabri efektif; (2) pembelajaran geometri berbantuan Geogebra efektif; (3) terdapat perbedaan keefektifan pembelajaran geometri berbantuan Geogebra dan Cabri; (4) pembelajaran geometri berbantuan Geogebra lebih efektif dari pada pembelajaran geometri berbantuan Cabri.
\end{abstract}

Kata Kunci: Cabri, Geogebra, prestasi belajar, berpikir kreatif, dan self-efficacy

\section{Geometry Instruction Using Cabri and Geogebra in Terms of Achievement, Creative Thinking, and Self-Efficacy}

\begin{abstract}
This study aimed to describe and to compare the effectiveness geometry instruction using Cabri and Geogebra in terms of the achievement, creative thinking, and self-efficacy of the students junior high schools. This research was a quasi-experimental research with the pretest-posttest nonequivalent group design. This study used two experimental groups without control groups. The population of the study was all grade VII students of Junior High School Saint Mary Banjarmasin. The sample of two classes (class VII ${ }_{A}$, and class $V I I_{B}$ ) was established randomly. Class VII ${ }_{A}$ got geometry instruction with Cabri and class VII ${ }_{B}$ got geometry instruction with Geogebra. The results show that in terms of students' academic achievement, creative thinking, and self-efficacy: (1) geometry instruction using by Cabri was effective; (2) geometry instruction using by Geogebra was effective; (3) there was a difference in the instruction using Cabri and that using Geogebra; (4) geometry instruction using Geogebra was more effective than geometry instruction using Cabri.
\end{abstract}

Keywords: Cabri, Geogebra, academic achievement, creative thinking, and self-efficacy

How to Cite: Saputra, P. (2016). Pembelajaran geometri berbantuan geogebra dan cabri ditinjau dari prestasi belajar, berpikir kreatif dan self-efficacy. PYTHAGORAS: Jurnal Pendidikan Matematika, 11(1), 59-68. doi:http://dx.doi.org/10.21831/pg.v11i1.9680

Permalink/DOI: http://dx.doi.org/10.21831/pg.v11i1.9680 


\section{PENDAHULUAN}

Pemerintah memberikan prioritas yang tinggi pada perkembangan sektor pendidikan, didasarkan pada asumsi bahwa melalui pendidikan, pembangunan bangsa Indonesia akan berhasil dengan baik. Didukung dari hasil minyak bumi, gas alam, kekayaan hewani, dan kekayaan hayati tanpa sentuhan teknologi tentulah tidak dapat dikembangkan secara maksimal. Sentuhan teknologi ini dimulai dari tingkat awal sampai yang tertinggi. Utamanya untuk memiliki kompetensi teknologi tingkat tinggi diperlukan warga negara yang memiliki pendidikan tinggi pula. Namun dibalik perkembangan itu, warga negara Indonesia tersebut, masih menghadapi per-masalahan yang berat, yaitu kualitas sumber daya manusianya sampai saat ini masih di bawah negara-negara tetangga.

Hal tersebut dapat dilihat pada salah satu kualitas kemampuan siswa menengah pertama dalam matematika di Indonesia pada skala internasional yang cukup memprihatinkan. Fakta ini bersumber dari NCTM (2009, p.135). Penelitian ini tujuannya untuk perbandingan atau benchmarking literasi matematika di berbagai negara di dunia. Menempatkan posisi Indonesia pada ranking 61 dari 65 negara partisipan. Fakta lainnya yang cukup memprihatinkan, bersumber dari hasil riset Global Creativity Index (2011, p. 41). Penelitian ini melakukan perbandingan kreativitas dalam berbagai inovasi dan teknologi diberbagai negara di dunia. yang menempatkan posisi Indonesia pada peringkat 81 dari 82 negara yang menjadi partisipan.

Banyak faktor yang diduga sebagai penyebab masih rendahnya kualitas kemam-puan matematika siswa sekolah. Salah satunya adalah pembelajaran matematika yang masih dianggap sulit oleh siswa. Contohnya, salah satu materi yang cukup sulit dalam pembelajaran matematika adalah geometri. Hal tersebut terungkap dari persentase penguasaan materi soal matematika, ujian nasional SMP Santa Maria Banjarmasin sebagaimana disajikan pada Tabel 1. Tabel itu menunjukkan bahwa prestasi belajar pada geometri khususnya materi bangun datar segi empat dan segitiga mulai dari UN tahun 2008 hingga tahun 2010 masih berada di bawah standar KKM pada sekolah SMP Santa Maria Banjarmasin yaitu 70. Berdasarkan hasil wawancara, guru matematika SMP Santa Maria Banjarmasin mengatakan bahwa pembelajaran geometri termasuk pembelajaran yang sulit bagi siswanya, khususnya pada materi bangun datar (segi empat dan segitiga). Salah satu faktor yang cukup menjadi pertimbangan adalah faktor usia anak yang masih baru saja lulus dari sekolah dasar. Pada usia seperti itu siswa masih tahap pengalaman pictorial/gambar (iconic), yang mana masih sangat membutuhkan visualisasi spasial melalui serangkaian gambar-gambar atau grafik untuk memahami bentuk geometri secara jelas.

Faktor lainnya, pokok bahasan bangun segitiga dan segi empat merupakan pokok bahasan terakhir pada semester II, sehingga banyak mengaitkan konsep materi sebelumnya yang berkaitan. Selain itu juga, siswa sering terbalik dalam memahami sifat-sifat bangun datar dalam bangun segi empat. Salah satu contohnya, pemahaman sifat-sifat pada persegi dan belah ketupat yang mirip (sisi-sisi yang berdekatan sama panjang) sehingga me-nyamakan bangun persegi adalah belah ketupat. Dalam proses pembelajaran matematika, guru juga masih menggunakan peralatan seadanya seperti busur, penggaris, dan papan tulis untuk menjelaskan materi. Hal tersebut juga menjadi faktor penting dimana minimnya inisiatif guru menyediakan media belajar/alat bantu dalam mengatasi permasalahan yang terjadi antara kebutuhan visualisasi spasial kepada siswa, faktor umur anak, dan pentingnya penggunaan media belajar yang mampu memberikan pemahaman yang lebih luas kepada anak.

Tabel 1. Hasil Ujian Nasional Matematika di SMP Santa Maria Banjarmasin

\begin{tabular}{cllll}
\hline \multirow{2}{*}{ Tahun } & \multicolumn{1}{c}{ Kemampuan yang Diuji } & \multicolumn{3}{c}{ Daya Serap } \\
\cline { 3 - 5 } $2008 / 2009$ & $\begin{array}{l}\text { Menentukan luas bangun datar yang dibentuk oleh segiempat dan } \\
\text { segitiga }\end{array}$ & 50,00 & 68,35 & 72,65 \\
$2009 / 2010$ & $\begin{array}{l}\text { Menyelesaikan soal cerita dengan menggunakan konsep luas segi } \\
\text { empat }\end{array}$ & 40,00 & 56,11 & 73,16 \\
$\begin{array}{l}\text { Menentukan besar sudut pada bangun datar antar 2 sudut pada } \\
\text { bangun tersebut }\end{array}$ & 61,67 & 68,14 & 79,27 \\
$\begin{array}{l}\text { Menyelesaikan masalah yang berkaitan dengan luas gabungan dua } \\
\text { bangun datar }\end{array}$ & 57,80 & 52,05 & 66,39 \\
\hline Menghitung luas gabungan dua bangun datar & 68,81 & 65,35 & 75,75 \\
\hline
\end{tabular}


Mengamati proses belajar mengajar di lapangan, guru juga masih menerapkan pembelajaran konvensional, umumnya guru lebih mendominasi proses belajar mengajar sehingga pembelajaran cenderung monoton yang menyebabkan siswa merasa jenuh dan tidak menarik. Hal ini juga berakibat, minimnya pengalaman yang bermakna dibenak siswa untuk bisa memahami konsep bangun segitiga dan segi empat. Selain itu juga guru belum menerapkan pembelajaran yang memacu siswa untuk berpikir kreatif. Alasannya karena guru harus dikejar oleh waktu untuk menyelesaikan kurikulum yang diformalkan.

Padahal dengan menerapkan pembelajaran kreatif, tentunya guru matematika akan memberi tantangan tersendiri kepada siswa-siswinya dalam upaya membiasakan mengasah kemampuan berpikir kreatif yang dimiliki. Perlunya pembiasaan pembelajaran kreatif, bertujuan agar siswa terlibat lebih dari sekedar pembelajaran hafalan, meniru, tugas-tugas dengan kertas dan pensil, dan hanya sedikit memberi tantangan. Tujuan-tujuan pembelajaran kreatif sudah jelas tertulis pada Permendiknas Nomor 22 Tahun 2006, bahwa tujuan standar isi mata pelajaran matematika yang mana membekali peserta didik dengan kemampuan berpikir logis, analitis, sistematis, kritis, dan kreatif, serta memiliki kemampuan bekerjasama. Kompetensi tersebut diperlukan agar peserta didik dapat memiliki kemampuan memperoleh, mengelola, dan memanfaatkan informasi untuk bertahan hidup pada keadaan yang selalu berubah, tidak pasti, dan kompetitif.

Selain dari dukungan pemerintah, para psikolog juga menganggap kemampuan berpikir kreatif dalam pembelajaran sangat penting. Munandar (2010, p.17) menyatakan bahwa siswa perlu belajar bagaimana menggunakan potensi mereka seoptimal mungkin untuk menemukan jawaban yang inovatif terhadap masalah. Dengan memadukan ide dan pemecahan masalah secara kreatif di dalam kurikulum, guru telah membantu memper-siapkan siswa untuk masa depan yang penuh tantangan. Pendapat lain dikemukakan oleh Gardner (Beetlestone, 2011, p.28) mengemukakan kemampuan berpikir kreatif adalah hal yang vital dari pemungsian kognitif dan dapat dipandang sebagai bentuk intelejensia. Oleh karena itu, sangatlah perlu untuk memberikan perhatian lebih pada proses pembelajaran yang kreatif dalam matematika saat ini.
Pembelajaran matematika yang kreatif juga akan berimplikasi pada kemampuan berpikir kreatif siswa yang melibatkan keingintahuan, kemampuan menemukan, eksplorasi, pencarian kepastian dan antusiasme yang semuanya merupakan kualitas-kualitas yang sangat besar yang terdapat pada siswa, khususnya pada bidang matematika. Adapun identifikasi kemampuan berpikir kreatif dilakukan melalui beberapa cara yang meliputi ukuran kemampuan berpikir kreatif, orisinilitas, imagenery kreatif, dan persepsi diri kreatif. Guilford (Munandar, 2011, p.65) menyatakan yang terutama berkaitan dengan kemampuan berpikir kreatif lebih menekankan berpikir secara divergen sebagai operasi mental yang menuntut penggunaan kemampuan berpikir kreatif, meliputi kelancaran, kelenturan, orisinilitas dan elaborasi (perincian).

Beberapa masalah yang telah disebutkan sebelumnya patut diduga bahwa proses pembelajaran yang berlangsung kurang mampu memberikan hasil yang maksimal dan merupakan masalah yang harus dicarikan solusinya. Dalam meningkatkan keefektifan pembelajaran, di era globalisasi ini, tentunya sekolah diharapkan menggunakan segala macam sumber belajar. Hal ini dikarenakan proses pembelajaran bersifat sistemik yang harus kita perhatikan dengan baik. Pembelajaran dikatakan sistem karena di dalamnya memiliki komponen-komponen yang saling berkaitan satu sama lain. Komponen tersebut terdiri atas tujuan, materi, metode, media dan evaluasi.

Inovasi-inovasi komponen pembelajaran saat ini juga membawa paradigma baru dalam proses pembelajaran itu sendiri, dimana guru dan siswa akan sama-sama memainkan peranan penting dalam kegiatan pembelajaran. Inovasi dalam pembelajaran juga menempatkan teknologi sebagai komponen penting bagi proses pembelajaran. Bahkan NCTM (2000, p. 11) juga memberikan apresisasi kepada teknologi sebagai salah satu dari 6 pilar utama dalam proses pembelajaran matematika sekolah. Penggunaan teknologi yang saat ini begitu pesat perkembangannya adalah komputer. Penggunaan komputer diyakini sangat berpengaruh dan mampu meningkatkan kemampuan berpikir, seperti kemampuan berpikir kreatif siswa. Pertimbangan ini layak sekali untuk diperhitungkan mengingat komputer sangatlah membantu proses pembelajaran demi ketercapaian hasil belajar yang maksimal.

Bagian terpenting dalam pembelajaran berbantuan komputer selain dapat meningkat- 
kan kreativitas dan prestasi belajar, ternyata juga dapat membangkitkan keinginan dan minat baru, membangkitkan motivasi dan merangsang kegiatan belajar, dan bahkan membawa pengaruhpengaruh psikologis terhadap siswa. Penggunaan komputer juga memungkinkan kesempatan yang seluas mungkin bagi siswa untuk belajar secara mandiri. Semua pengalaman belajar dikemas dalam program pembelajaran berbasis komputer dan siswa dapat mengerjakannya secara mandiri di labotarium komputer, atau bahkan di rumah sekalipun bila merasa belum puas di sekolah. Motivasi secara intrinsik dan ekstrinsik tersebut memberikan penguatan kepada kemampuan diri siswa. Tujuannya, siswa dapat meyakinkan kemampuan diri dan memberikan hasil belajar yang positif buat siswa.

Menurut Santrock (2007, p.152), keyakinan bahwa seseorang dapat mengusai situasi dan memberikan hasil yang inginkan disebut dengan self-efficacy. Pendapat lain dari Bandura (Santrock, 2007, p.152) mengemukakan bahwa self-efficacy merupakan suatu faktor penting yang menjelaskan apakah remaja akan berhasil atau tidak. Dapat diperjelas bahwa hal ini adalah sebuah kesadaran seseorang akan kemampuannya sendiri dalam menangani lingkungan secara efektif.

Pengukuran self-efficay siswa terhadap pembelajaran matematika belum pernah dilakukan kelas yang diampu oleh guru mata pelajaran. Pada hasil wawancara dan obervasi, siswa masih cenderung apatis terhadap matematika. Hal ini juga bisa diduga mengakibatkan kepercayaan diri pada kemampuan (self-efficacy) siswa menurun atau berkurang. Sangatlah perlu diperhatikan, bila seorang siswa sudah tidak percaya dengan kemampuannya/selfefficacy rendah, hal tersebut akan sangat mengganggu proses pembelajaran yang harus setiap hari berlanjut pada materi berikutnya. Hal ini mengindikasi-kan pembelajaran masih berpusat kepada aspek kognitif, sehingga mengurangi kesempatan mengembangkan self-efficacy pada siswa yang berpengaruh pada keberhasilan siswa dalam pembelajaran matematika.

Bandura (Friedman \& Schustack, 2008, p.284) juga mengemukakan bahwa seseorang memungkinkan mempunyai self-efficacy yang lebih tinggi dan rendah dalam aspek yang lebih luas dan umum. Self-efficacy yang rendah mungkin akan berimplikasi negatif pada perilaku siswa. Salah satunya siswa mungkin menghindari pelajaran yang banyak tugasnya, khususnya tugas-tugas yang menantang, sedangkan siswa yang mempunyai self-efficacy yang tinggi, menganggap hal itu adalah tantangan dan menginginkannya untuk diselesaikan.

Keyakinan pada kemampuan diri sendiri (self-efficacy) merupakan salah satu faktor nonkognitif yang berpengaruh terhadap hasil belajar matematika. Kondisi seperti ini tidak bergantung dari sebuah keberuntungan, orang lain dan faktor eksternal yang tidak terkendali. Melihat vitalnya peran self-efficacy di dalam proses pembelajaran, diharapkan media pembelajaran berbantuan komputer dapat memberikan sumber belajar bervariasi dan pengalaman bermakna sehingga memacu self-efficacy ke arah yang positif menjadi salah satu tujuan yang ingin dicapai oleh peneliti.

Pada beberapa uraian sebelumnya telah dijelaskan mengenai keterkaitan antara penggunaan komputer terhadap motivasi ekstrinsik dan intrinsik pada siswa yang membentuk suatu kemampuan seperti self-efficacy, beserta vitalnya peran self-efficacy siswa dalam pembelajaran. Ternyata, kelebihan komputer yang masih dapat dieksplorasi lebih mendalam, salah satunya adalah kemampuan dalam mengitegrasikan kompenan. Kompenan itu ialah warna, musik, dan grafik (graphic). Hal ini menyebabkan komputer mampu menyampaikan materi pelajaran dengan tingkat realisme yang tinggi (Warsita, 2008, p.139). Dengan kata lain komputer dapat mengurangi tingkat abstraksi sebuah materi pelajaran yang dipelajari oleh siswa dalam proses pembelajaran. Potensi-potensi komputer ini sangatlah cocok untuk mengurangi tingkat abstraksi pemahaman siswa terhadap materi geometri di sekolah. Fakta menunjukkan dalam mempelajari geometri, siswa terkadang me-ngalami kesulitan. Kesulitannya adalah mempelajari objek bersifat abstrak bila hanya disampaikan secara verbal. Penyebabnya adalah siswa SMP tahap berpikirnya masih dalam tahap realistik.

Melihat banyaknya keuntungan pembelajaran menggunakan komputer, maka pemilihan komputer dirasa tepat untuk menjadi alat yang baik untuk digunakan dalam pembelajaran geometri. Penggunaan komputer tentunya sangat berkaitan dengan software yang dikembangkan sesuai tujuannya masing-masing. Banyaknya program piranti lunak dalam pembelajaran yang telah berkembang pada abad ke-21 ini menawarkan kemampuan untuk membantu proses belajar dan mengajar pada bidang geometri. Ada beberapa piranti lunak dalam matematika khususnya dalam bidang geometri seperti Maple, Matlab, 
Graph, Openeuclid, Cabri, Geogebra dan lain sebagainya.

Pemilihan software juga berdasarkan pada kemampuan siswa yang menggunakan dalam proses pembelajarannya nanti. Setiap software memiliki tingkat kesulitan yang bervariasi bergantung pada tingkat pendidikan pengguna. Oleh karena itu dipilih dua software yang easy user/mudah digunakan dan sesuai dengan taraf kemampuan siswa sekolah menengah yaitu Cabri dan Geogebra. Kedua software ini merupakan perangkat lunak matematika dinamis untuk pendidikan di sekolah menengah dan menunjang ekspolarasi pengetahuan geometri, kalkulus, dan aljabar. Cabri dan Geogebra adalah software pembelajaran matematika dengan sistem geometri dinamis yang dapat melakukan konstruksi titik-titik, sudut-sudut, vektor-vektor, segmen, bentuk-bentuk bangun datar, keliling bangun datar, dan luas bangun datar. Selain itu, Cabri dan Geogebra adalah program komputer yang juga mampu mengeksplorasi bentuk-bentuk geometris yang sederhana dan kompleks sekalipun, program ini juga membantu siswa untuk menunjukkan bentuk dan bangun geometri pada layar komputer cukup dengan melakukan sintaks sederhana.

Melihat besarnya potensi dari software Geogebra dan Cabri untuk tujuan pembelajaran geometri, diharapkan dengan penggunaan software Geogebra dan Cabri memungkinkan siswa melakukan banyak eksperimen dan eksplorasi untuk mengkontruksi pemahaman konsep geometri sehingga dapat merangsang self-efficacy, berpikir kreatif dan peningkatan prestasi siswa. Fitriyani \& Sugiman (2014) mengemukakan bahwa pembelajaran geometri menggunakan perangkat pembelajaran dengan pendekatan IDEAL berbantuan Geogebra efektif ditinjau dari prestasi dan motivasi belajar siswa. Sedangkan untuk penggunaan Cabri, menurut Sugiyono (2007) dengan software ini lukisan yang dihasilkan akan lebih akurat dan cepat selesai, serta dapat menarik minat orang/siswa untuk menggunakannya. Hal ini menunjukkan dari sisi penggunaan sofware ini cukup praktis untuk digunakan dalam pembelajaran geometri. Hal ini tentunya sudah sangat diperlukan sekali, karena peniliti masih menganggap salah satu permasalahan di lapangan yang dianggap penting yaitu minimnya pemanfaatan potensi penggunaan komputer berbantuan Geogebra dan Cabri sebagai media pembelajaran untuk mengeksplorasi pentingnya berpikir kreatif dan selfefficacy untuk meningkatkan prestasi siswa.
Sebagai usaha sadar oleh peneliti untuk mencari alternatif media pembelajaran yang paling cocok dan perlunya mengetahui keefektifan media pembelajaran yang beredar luas, peneliti tertarik untuk melakukan penelitian tentang Keefektifan Pembelajaran Geometri berbantuan Geogebra dan Cabri ditinjau dari prestasi, kemampuan berpikir kreatif matematika dan self efficacy pada siswa SMP Santa Maria Banjarmasin tahun ajaran 2012/2013. Berdasarkan latar belakang tersebut maka tujuan penelitian ini adalah untuk mendeskripsikan (1) keefektifan pembelajaran geometri berbantuan Cabri dan Geogebra ditinjau dari prestasi, berpikir kreatif dan Self efficacy pada siswa SMP Santa Maria Banjarmasin; dan (2) membandingkan keefektifan pembelajaran geometri berbantuan Geogebra dan pembelajaran geometri berbantuan Cabri ditinjau dari prestasi belajar, berpikir kreatif dan self-efficacy pada siswa SMP Santa Maria Banjarmasin.

\section{METODE}

Jenis penelitan ini adalah penelitan eksperimen semu. Pada penelitian ini digunakan dua kelompok dalam satu sekolah. Langkahlangkah yang dilakukan dalam penelitan eksperimen berupa: (1) mengambil secara acak dua kelompok dari kelompok belajar (kelas) yang ada; (2) memberikan pretest (tes awal) dan angket pada kedua kelompok; (3) melakukan treatment dengan penggunaan dua media belajar berbantuan Geogebra dan Cabri pada masingmasing kelompok; (4) memberikan posttes (tes akhir) dan angket pada kedua kelompok.

Rancangan eksperimen yang digunakan adalah pretest-posttest, Nonequivalent Group Design. Penelitian ini akan dilaksanakan di SMP Santa Maria Banjarmasin, Jalan Rantauan Timur I, Kelayan Barat Banjarmasin Selatan. Waktu penelitian direncanakan sejak bulan Juli 2012 sampai Juni 2013. Populasi dalam penelitian ini adalah seluruh siswa kelas VII SMP Santa Maria Banjarmasin, tahun pelajaran 2012/2013. Jumlah siswa kelas VII SMP Santa Maria Banjarmasin, saat pelaksanaan penelitian adalah 180 siswa, tersebar dalam 5 rombongan belajar (kelas) paralel yang dipilih 2 kelas dengan cara cluster random sampling, yaitu kelas $V I I_{A}$ dan kelas $V I I_{B}$ sebagai sampel penelitian. Jumlah siswa yang menempati kelas $V I I_{A}$ dan kelas $V I I_{B}$ masing-masing adalah 34 dan 36 siswa, sehingga sampel berjumlah 70 siswa. Selanjutnya dua kelas yang terpilih diacak kembali untuk pemberian perlakuan, hasilnya kelas $V I I_{A}$ diberikan 
pembelajaran geometri berbantuan Cabri dan kelas $V I I_{B}$ diberikan pembelajaran geometri berbantuan Geogebra.

Variabel yang diteliti dalam penelitian ini meliputi variabel bebas, yaitu pembelajaran geometri yang terdiri atas penggunaan bantuan software Geogebra, dan penggunaan bantuan software Cabri dan variabel terikat yang terdiri atas self-efficacy, berpikir kreatif, dan prestasi belajar matematika. Teknik pengumpulannya dibagi atas dua, yaitu tes tertulis yang digunakan dalam pengambilan data tinjauan prestasi belajar dan data tinjauan berpikir kreatif, teknik angket untuk memperoleh data tentang self-efficacy siswa. Validitas tes dan angket menggunakan menggunakan expert judgement dan reliabilitasnya dianalisis menggunakan formula Kuder Richardson 20 (KR 20) dan Alpha Cronbach.

Uji asumsi dalam penelitian ini meliputi normalitas baik multivariat dan univariat, serta homogenitas baik multivariat dan univariat. Dalam deskripsi statistik penelitian ini meliputi kategorisasi dan peningkatan rata-rata kelas dari pretest ke postest, sedangkan pengujian hipotesis menggunakan analisis statistik inferensial meliputi uji keefektifan (one sample t-test), uji perbedaan (multivariate two-group test (Hotelling's $\left.T^{2}\right)$ ), dan Uji lanjut univariat (independent sample t-test) dengan total hipotesis adalah 11 hipotesis.

\section{HASIL DAN PEMBAHASAN}

Rata-rata pretest pada kelas $\boldsymbol{V I I}_{\boldsymbol{A}}$ adalah 18,59 dan $\boldsymbol{V I I}_{\boldsymbol{B}}$ adalah 21,22 , sedangkan ratarata hasil postest prestasi belajar pada kelas $\boldsymbol{V I I}_{\boldsymbol{A}}$ adalah 74,35 dan $\boldsymbol{V I I}_{\boldsymbol{B}}$ adalah 81,22 . Untuk kriteria ketuntasan hasil belajar, rata-rata postest prestasi belajar matematika pada kelas $\boldsymbol{V I I}_{\boldsymbol{A}}$ dan kelas $\boldsymbol{V I I} \boldsymbol{I}_{\boldsymbol{B}}$ sudah memenuhi standar ketuntasan minimal yaitu 70 atau nilai rata-rata $\geq 70$. Kategorisasi Pretest prestasi belajar pada kelas $V I_{A}$ menunjukkan bahwa $100 \%$ nilai siswa berada dibawah nilai standar KKM sekolah yaitu nilai 70. Oleh karena itu, semua siswa belum memenuhi kategori tuntas. Sedangkan untuk nilai postest, persentase prestasi belajar siswa dalam kategori tuntas sebesar $82,35 \%$ dan yang tidak tuntas $17,65 \%$. Kategorisasi pretest prestasi belajar pada kelas $V I I_{B}$ menunjukkan bahwa $100 \%$ nilai siswa di bawah nilai standar KKM sekolah yaitu 70. Oleh karena itu, semua siswa belum memenuhi kategori tuntas. Sedangkan untuk nilai postest prestasi belajar, persentase siswa dalam kategori tuntas $97,22 \%$ dan yang tidak tuntas $2,78 \%$. Untuk peningkatan rata-rata dari selisih rata-rata pretest dan rata-rata postest yang sudah dilakukan pada kelas $\boldsymbol{V I I}_{\boldsymbol{A}}$ sebesar 55,76 dan pada kelas $\boldsymbol{V I I}_{\boldsymbol{B}}$ sebesar 60,00.

Rata-rata pretest kemampuan berpikir kreatif pada kelas $\boldsymbol{V I I}_{\boldsymbol{A}}$ adalah 2.47 dan pada $\boldsymbol{V I I}_{\boldsymbol{B}}$ adalah 2.81, sedangkan untuk rata-rata hasil postest berpikir kreatif pada kelas $\boldsymbol{V I I}_{\boldsymbol{A}}$ adalah 48,53 dan pada kelas $\boldsymbol{V} \boldsymbol{I I}_{\boldsymbol{B}}$ adalah 57,47. Berdasarkan kriteria minimum passing grade yang telah telah ditetapkan peneliti, untuk ratarata postest dari data berpikir kreatif siswa pada kelompok pembelajaran geometri berbantuan Cabri pada kelas $\boldsymbol{V I I}_{\boldsymbol{A}}$ dan kelompok pembelajaran berbantuan Geogebra pada kelas $\boldsymbol{V I I}_{\boldsymbol{B}}$ sudah memenuhi kriteria minimum passing grade yaitu di atas 42,79atau skor rata-rata kedua kelas $>42,79$. Kategorisasi hasil pretest semua siswa di kelas $\boldsymbol{V I I}_{\boldsymbol{A}}$ kurang dari standar minimum pasing grade berpikir kreatif dengan persentase $100 \%$ siswa dan hasil pretest berpikir kreatif semua siswa berada dalam kategori rendah. Sedangkan untuk nilai posttest berpikir kreatif, siswa yang memiliki kemampuan berpikir kreatif dalam kategori tinggi sebesar $58,82 \%$, kategori sedang sebesar $23,53 \%$ dan untuk kategori rendah sebesar $17,65 \%$. Kategorisasi pretest semua siswa di kelas $\boldsymbol{V I I}_{\boldsymbol{B}}$ kurang dari standar minimum pasing grade berpikir kreatif dengan persentase $100 \%$ dan hasil pretest berpikir kreatif semua siswa berada dalam kategori rendah. Sedangkan untuk nilai postest berpikir kreatif, untuk siswa yang memiliki kemampuan berpikir kreatif dalam kategori tinggi sebesar $66,67 \%$, kategori sedang sebesar $25,00 \%$ dan untuk kategori rendah sebesar $2,78 \%$. Untuk peningkatan rata-rata dari selisih rata-rata pretest dan rata-rata postest yang sudah dilakukan pada kelas $\boldsymbol{V I I}_{\boldsymbol{A}}$ sebesar 46,06 dan pada kelas $\boldsymbol{V} \boldsymbol{I I}_{\boldsymbol{B}}$ sebesar 54,66.

Rata-rata skor pretest self-efficacy pada kelas $\boldsymbol{V I I}_{\boldsymbol{A}}$ adalah 92,76 dan pada kelas $\boldsymbol{V I \boldsymbol { I } _ { \boldsymbol { B } }}$ adalah 89,03, sedangkan rata-rata hasil skor postest self-efficacy pada $\boldsymbol{V I I}_{\boldsymbol{A}}$ adalah 111,76 dan pada kelas $\boldsymbol{V I I} \boldsymbol{I}_{\boldsymbol{B}}$ adalah 120,83 . Berdasarkan kriteria minimum passing grade yang telah telah ditetapkan peneliti, untuk rata-rata postest selfefficacy siswa pada kelompok pembelajaran geometri berbantuan Cabri pada kelas $\boldsymbol{V I I}_{\boldsymbol{A}}$ dan kelompok pembelajaran berbantuan Geogebra pada kelas $\boldsymbol{V I I}_{\boldsymbol{B}}$ sudah memenuhi kriteria minimum passing grade yaitu di atas 95 atau skor rata-rata postest self-efficacy siswa kedua kelas $>$ 95. Kategorisasi pretest self-efficacy siswa pada kelas $\boldsymbol{V I I}_{\boldsymbol{A}}$ dalam kategori sangat tinggi sebesar $0,00 \%$, tinggi sebesar $23,53 \%$, sedang 
sebesar $61,76 \%$, rendah sebesar $8,82 \%$, dan sangat rendah sebesar $5,88 \%$. Sedangkan untuk hasil postest self-efficacy siswa yang termasuk dalam kategori sangat tinggi sebesar 26,47\%, tinggi sebesar 52,94\%, sedang sebesar 20,59\%, dan untuk kategori rendah dan sangat rendah sebesar $0,00 \%$. Kategorisasi pretest self-efficacy siswa pada kelas $\boldsymbol{V I I}_{\boldsymbol{B}}$ dalam kategori sangat tinggi sebesar $0,00 \%$, tinggi sebesar $22.22 \%$, sedang sebesar $61.11 \%$, rendah sebesar $5.56 \%$, dan sangat rendah sebesar $11.11 \%$. Sedangkan untuk hasil postest self-efficacy siswa yang termasuk dalam kategori sangat tinggi sebesar $38,24 \%$, tinggi sebesar $58,82 \%$, sedang sebesar $8,82 \%$, dan untuk kategori rendah dan sangat rendah sebesar $0.00 \%$. Untuk peningkatan ratarata dari selisih rata-rata pretest dan rata-rata postest yang sudah dilakukan pada kelas $\boldsymbol{V I I}_{\boldsymbol{A}}$ sebesar 19,00 dan pada kelas $\boldsymbol{V I I}_{\boldsymbol{B}}$ sebesar 31,80 .

Untuk mengetahui apakah terdapat perbedaan kemampuan awal antara kelompok pembelajaran yang akan diberikan perlakuan pembelajaran geometri berbantuan Cabri pada kelas $V I I_{A}$ dan pembelajaran pembelajaran geometri berbantuan Geogebra pada kelas $V I_{B}$ ditinjau dari variabel prestasi belajar, berpikir kreatif dan self-efficacy siswa secara simultan dilakukan uji multivariat (MANOVA) dengan SPSS 20.00 for windows. Hasil analisis uji two group MANOVA disajikan pada Tabel 2.

Tabel 2. Uji MANOVA Sebelum Perlakuan

\begin{tabular}{cccc}
\hline Test Name & Value & F & Sig. Of F \\
\hline Hottelling's Trace & $\mathbf{0 , 0 4 4}$ & $\mathbf{0 , 9 5 7 ^ { \mathrm { a } }}$ & $\mathbf{0 , 4 1 8}$ \\
\hline
\end{tabular}

Berdasarkan Tabel 2, dengan menggunakan kriteria Hottelling's Trace diperoleh nilai $\mathrm{F}$ sebesar 0,957 dengan nilai signifikansi 0,418. Dengan taraf signifikansi sebesar 0,05 maka nilai signifikansi yang diperoleh lebih besar dari 0,05 sehingga $H_{0}$ diterima atau tidak terdapat perbedaan kemampuan awal siswa antara kelas $V I I_{A}$ dengan kelas $V I I_{B}$ ditinjau dari prestasi belajar matematika, berpikir kreatif dan selfefficacy siswa.

Analisis keefektifan dilaksanakan untuk mengetahui efektif tidaknya kedua kelompok pembelajaran tersebut ditinjau dari prestasi belajar, bepikir kreatif (BK) dan self-efficacy siswa. Uji keefektifan ini menggunakan uji One sample t-test dengan taraf signifikansi $\alpha=0.05$. Hasil uji tersebut dapat Tabel 3.
Tabel 3. Uji t One Sample Kelompok Pembelajaran Geometri berbantuan Cabri dan Kelompok Pembelajaran Geometri Berbantuan Geogbra

\begin{tabular}{|lcccccc|}
\hline Kelompok & Variabel & $\overline{\boldsymbol{x}}$ & $\boldsymbol{s} \boldsymbol{d}$ & $\boldsymbol{d} \boldsymbol{f}$ & $\boldsymbol{t}_{\text {hitung }}$ & $\boldsymbol{t}_{\text {tabel }}$ \\
\hline Pembelajaran & Prestasi & 74,35 & 8,70 & 33 & 2,923 & 2,035 \\
Geometri & $\mathrm{BK}$ & 48,53 & 14,91 & 33 & 2,249 & 2,035 \\
berbantuan & Self-Efficacy & 111,76 & 12,79 & 33 & 7,645 & 2,035 \\
Cabri & Prestasi & 81,22 & 9,06 & 35 & 7,437 & 2.030 \\
Pembelajaran & $\mathrm{BK}$ & 57,47 & 14,73 & 35 & 5,987 & 2.030 \\
Geometri & Self-Efficacy & 120,83 & 15,48 & 35 & 10,016 & 2.030 \\
Berbantuan & & & & & \\
Geogbra & & & & & &
\end{tabular}

Pada Tabel 3 dapat diketahui bahwa pembelajaran geometri berbantuan Cabri dan pembelajaran geometri berbantuan Geogbra ditinjau dari prestasi belajar, bepikir kreatif (BK) dan self-efficacy siswa memiliki nilai $t_{\text {hitung }}$ berturutturut adalah 2,923 dan 7,437 untuk prestasi, 2,249 dan 5,987 untuk berpikir kreatif dan 7,645 dan 10,016 untuk self-efficacy siswa. Secara keseluruhan $t_{\text {hitung }}$ yang didapatkan dari kedua kelompok pembelajaran lebih besar dari $t_{\text {tabel }}$, sehingga dapat disimpulkan bahwa kelompok pembelajaran geometri berbantuan Cabri dan kelompok pembelajaran geometri berbantuan Geogebra efektif ditinjau dari prestasi belajar, berpikir kreatif dan self-efficacy siswa.

Untuk menyelidiki perbedaan keefektifan pembelajaran geometri berbantuan Cabri dan pembelajaran geometri berbantuan Geogebra ditinjau dari prestasi belajar matematika, berpikir kreatif (BK) dan self-efficacy siswa dilakukan secara simultan melaui uji multivariat. Berdasarkan kepentingan tersebut maka uji statistik two group MANOVA dilakukan untuk mengetahui apakah terdapat perbedaan mean atau tidak antara pembelajaran geometri berbantuan $\mathrm{Cabri}$ dan pembelajaran geometri berbantuan Geogebra ditinjau dari prestasi belajar matematika, berpikir kreatif (BK) dan self-efficacy siswa. Hasil analisis data dengan bantuan software SPSS 20 for windows disajikan pada Tabel 4.

Tabel 4. Hasil Uji Manova Kelompok Setelah Perlakuan

\begin{tabular}{ccccc}
\hline Test Name & F & $\begin{array}{c}\text { Hypoth. } \\
\text { DF }\end{array}$ & $\begin{array}{c}\text { Error } \\
\text { DF }\end{array}$ & $\begin{array}{c}\text { Sig. } \\
\text { of } \mathbf{F}\end{array}$ \\
\hline $\begin{array}{c}\text { Hottelling's } \\
\text { Trace }\end{array}$ & $7,459^{\mathrm{b}}$ & 3,000 & 66,000 & 0,418 \\
\hline
\end{tabular}

Berdasarkan Tabel 4, dapat diketahui bahwa dengan menggunakan uji Hotteling's Trace diperoleh $F_{\text {hitung }}=7,459$ dengan signifikansi = 0,000. Dengan demikian dapat disimpulkan bahwa $H_{o}$ ditolak atau terdapat perbedaan keefektifan pembelajaran geometri berbantuan 
Cabri dan pembelajaran geometri berbantuan Geogebra ditinjau dari prestasi belajar matematika, berpikir kreatif (BK) dan self-efficacy siswa.

Berdasarkan hasil uji MANOVA dapat diketahui bahwa terdapat perbedaan keefektifan pembelajaran geometri berbantuan Cabri dan pembelajaran geometri berbantuan Geogebra ditinjau dari prestasi belajar matematika, berpikir kreatif (BK) dan self-efficacy siswa, maka dilakukan statistik uji $t$ untuk menentukan kelompok-kelompok tertentu yang berkontribusi terhadap perbedaan secara keseluruhan. Untuk itu dilakukan uji univariat dari dua kelompok belajar tersebut. Hasil uji univariat disajikan pada Tabel 5.

Tabel 5. Hasil Uji Univariat

\begin{tabular}{lccc}
\hline \multicolumn{1}{c}{ Variabel } & $\mathbf{t}_{\text {hitung }}$ & df & $\mathbf{t}_{(\mathbf{0 , 0 1 7}, \mathbf{6 8})}$ \\
\hline Prestasi Belajar & 3,231 & 68 & 2,164 \\
BK & 2,524 & 68 & 2,164 \\
Self-Efficacy & 2,663 & 68 & 2,164 \\
\hline
\end{tabular}

Berdasarkan Tabel 5 dapat diketahui bahwa $t_{\text {hitung }}$ untuk perbandingan rata-rata kelompok pembelajaran geometri berbantuan Geogebra dan pembelajaran geometri berbantuan Cabri ditinjau dari prestasi belajar, berpikir kreatif (BK), dan self-efficacy siswa selalu lebih besar dari $\boldsymbol{t}_{\left(0,017,{ }_{68)}\right.}=2,164$. Sehingga dapat disimpulkan bahwa (1) pembelajaran geometri berbantuan geogebra efektif dari pembelajaran geometri berbantuan Cabri ditinjau dari prestasi belajar matematika siswa; (2) pembelajaran geometri berbantuan Geogebra efektif dari pembelajaran geometri berbantuan Cabri ditinjau dari berpikir kreatif (BK) siswa; (3) Pembelajaran geometri berbantuan Geogebra efektif dari pembelajaran geometri berbantuan Cabri ditinjau dari self-efficacy siswa.

Hasil uji Hotelling Trace $\left(T^{2}\right)$ menunjukkan bahwa terdapat perbedaan yang signifikan antara keefektifan pembelajaran geometri berbantuan Geogebra dan Cabri ditinjau dari aspek prestasi belajar, berpikir kreatif (BK), dan selfefficacy siswa. Perbedaan ini memungkinkan untuk melanjutkan pengujian dengan uji $t$ dan hasilnya menunjukkan bahwa pembelajaran geometri berbantuan Geogebra lebih efektif dari pembelajaran geometri berbantuan Cabri ditinjau dari aspek prestasi belajar, berpikir kreatif (BK), dan self-efficacy siswa.

Penelitian-penelitian terdahulu menunjukkan bahwa pembelajaran geometri berbantuan Geogebra lebih efektif pada pembelajaran konvensional ditinjau dari berpikir kreatif siswa dan self-concept (Rahman, 2010, p.52). Begitu juga untuk pembelajaran geometri berbantuan Cabri lebih efektif dari pada pembelajaran konvensional dalam meningkatkan kemampuan pemecahan masalah siswa dan berpikir kreatif siswa (Krismiati, 2009, p.127). Jika dibandingkan dengan pembelajaran konvensional, pembelajaran geometri berbantuan Cabri maupun berbantuan Geogebra dari penelitian terdahulu jelas terlihat ada perbedaan, sedangkan untuk perbedaan keefektifan pembelajaran geometri Cabri dan geometri berbantuan Geogebra masih belum ditemukan ada penelitian yang relevan. Lalu disusunlah penelitian ini untuk membandingkan pembelajaran geometri berbantuan Cabri dan pembelajaran geometri berbantuan Geogebra.

Berdasarkan hasil uji $T^{2}$ Hotelling menunjukkan bahwa terdapat perbedaan keefektifan pembelajaran geometri berbantuan Geogebra dengan pembelajaran geometri berbantuan Cabri. Perbedaaan pada penilitian ini menjawab dugaan awal pada kerangka berpikir bahwa pembelajaran geometri berbantuan Cabri dapat dibandingkan pembelajaran geometri berbantuan Geogebra. Secara teoritis kedua software matematika ini, baik Cabri dan Geogebra mempunyai fungsi yang sama dalam membantu siswa mengeksplorasi materi geometri dua dimensi, akan tetapi dari kedua desain interface yang disediakan pada kedua software sedikit banyak memiliki perbedaan.

Menurut pengamatan peneliti di lapangan, software yang memiliki tingkat kompleksitas yang rendah, kesederhanaan pengoperasian, dan beberapa tool yang lengkap disediakan dari kedua software akan sangat berpengaruh dalam kecepatan siswa untuk memecahkan masalah pada LKS yang diberikan. Semakin cepat siswa memecahkan masalah pada LKS yang diberikan maka juga akan berpengaruh pada seberapa dalam siswa mengerti permasalahan yang diberikan dengan banyak melakukan eksplorasi pada kedua sofware.

Perbedaan yang dibuktikan dengan uji hipotesis ini menunjukan bahwa meskipun kedua software ini mempunyai fungsi yang sama efektif dalam mengeksplorasi materi geometri dua dimensi siswa kelas VII, tetapi memiliki kelemahan dan kelebihan masing-masing. Kelemahan dan kelebihan yang ada pada kedua software ini juga akan menyebabkan perbedaan hasil pula pada setiap variabel penelitian. Berikut dijelaskan juga perbedaan skor rata-rata kelas dari kedua pembalajaran baik pembelajaran 
geometri berbantuan Cabri dan Geogebra dari aspek yang diteliti.

Hasil independent samples $t$ test terhadap skor prestasi belajar, berpikir kreatif (BK), dan self-efficacy siswa menunjukan bahwa pembelajaran geometri berbantuan Geogebra lebih efektif dari pembelajaran geometri berbantuan Cabri. Berdasarkan pengamatan peneliti di lapangan, lebih efektifnya pembelajaran geometri berbantuan Geogebra daripada Cabri sangatlah dipengaruhi oleh faktor teknis dan fitur yang disajikan oleh kedua software. Dimana siswa akan cenderung menyukai software dengan tampilan menarik, mudah digunakan, dan beberapa fitur yang otomatis bisa langsung digunakan dalam pemrosesan masalah geometris yang diberikan pada LKS. Seberapa besar pengaruh-pengaruh psikologis seperti inilah yang membuat perbedaan penguatan pada kemampuan diri siswa (self-efficacy) dalam merangsang kegiatan pembelajaran untuk lebih aktif dari kedua kelas. Seperti yang diungkapkan oleh Santrock (2007, p.152) bahwa self-efficacy merupakan suatu faktor penting yang menjelaskan apakah remaja akan berhasil atau tidak.

Fakta yang diberikan, dari hasil independent samples $t$ test bahwa keefektifan pembelajaran geometri berbantuan Geogebra efektif dari pembelajaran geometri berbantuan Cabri ditinjau dari self-efficacy siswa. Keyakinan pada kemampuan diri sendiri (self-efficacy) merupakan salah satu faktor non-kognitif yang berpengaruh terhadapa hasil belajar matematika siswa. Senada dengan yang diungkapkan oleh Bandura (Friedman \& Schustack, 2008, p. 284) yang mengemukakan bahwa seseorang memungkinkan mempunyai self-efficacy yang lebih tinggi dan rendah dalam aspek yang lebih luas dan umum. Self-efficacy yang rendah mungkin akan berimplikasi negatif pada perilaku siswa. Salah satunya siswa mungkin akan menghindari pelajaran yang banyak tugasnya, khususnya tugas-tugas yang menantang, sedangkan siswa yang mempunyai self-efficacy yang lebih tinggi, menganggap hal itu adalah tantangan dan menginginkannya untuk diselesaikan. Hal ini juga diperkuat oleh hasil pengujian hasil independent samples $t$ test bahwa keefektifan pembelajaran geometri berbantuan Geogebra lebih baik dari pembelajaran geometri berbantuan Cabri ditinjau dari prestasi belajar dan berpikir kreatif (BK) siswa.

Secara keseluruhan, baik pembelajaran geometri berbantuan Cabri dan berbantuan Geogebra sangat membantu siswa berpikir secara mandiri dalam menyusun rencana dan menyelesaikan masalah, mengevaluasi hasil penyelesaian dan menyiapkan altenatif pemecahan yang lain. Oleh karena itu, kedua sofware ini sangat berpengaruh sekali pada berpikir kreatif siswa. Belajar secara mandiri berbantuan kedua software ini membuat siswa lebih aktif dalam pembelajaran, selain itu juga siswa lebih memahami permasalahan karena LKS yang dirancang untuk mengarahkan siswa untuk menemukan sendiri solusi permasalahan dengan bantuan kedua software masing-masing. Hal ini didukung oleh NCTM (2000, p. 237) yang mengungkapkan bahwa penggunaan media belajar komputer dalam matematika sekolah pada materi geometri dimensi dua dan dimensi tiga diperlukan untuk memeriksa, membangun, membuat, dan menguraikan kompleksitas pada bangun datar dan bangun ruang.

\section{SIMPULAN DAN SARAN}

\section{Simpulan}

Kesimpulan yang dapat diajukan oleh peneliti berdasarkan hasil peneitian ini adalah (1) pembelajaran geometri berbantuan Cabri efektif ditinjau dari aspek prestasi belajar, berpikir kreatif dan self-efficacy siswa; (2) Pembelajaran geometri berbantuan Geogebra efektif ditinjau dari aspek prestasi belajar, berpikir kreatif dan self-efficacy siswa; (3) Terdapat perbedaan kefeektifan pembelajaran geometri berbantuan Cabri dan pembelajaran geometri berbantuan geogebra ditinjau dari aspek prestasi belajar, berpikir kreatif dan self-efficay; (4) Pembelajaran geometri berbantuan Geogebra lebih efektif dari pembelajaran geometri berbantuan Cabri ditinjau dari aspek prestasi belajar matematika, berpikir kreatif dan self-efficacy siswa.

\section{Saran}

Berdasarkan hasil dan uraian tersebut, maka dapat dibuat suatu rekomendasi bahwa untuk aspek prestasi belajar, berpikir kreatif dan self-efficacy siswa, guru dapat menggunakan pembelajaran berbantuan Cabri dan Geobra, karena pembelajaran berbantuan Cabri dan Geobra terbukti dapat meningkatkan aspek prestasi belajar, berpikir kreatif dan self-efficacy siswa. Saran yang selanjutnya disampaikan kepada peneliti selanjutnya agar memperluas materi yang digunakan dalam penelitian, sehingga memungkinkan generalisasi yang lebih luas. 


\section{DAFTAR PUSTAKA}

Beetlestone, F. (2011). Strategi pembelajaran untuk melesatkan kreativitas siswa. (Terjemahan Narulita Yusron). Bandung: Nusa Media.

Fitriyani, W., \& Sugiman. (2014). Pengembangan perangkat pembelajaran teorema Pythagoras dengan pendekatan IDEAL berbantuan Geogebra. Jurnal Riset Pendidikan Matematika, 1(2), 268283.

Friedman, H.S \& Schustack, M. W. (2008). Kepribadian teori klasik dan riset modern. (Terjemahan Fransiska Dina Ikarini, Maria Hany, dan Andreas Provita Prima). Jakarta: Erlangga.

GCI (2011). Creativity and Prosperity: the global creativity index. Toronto: Martin Prosperity Institute.

Krismiati. (2009). Meningkatkan kemampuan pemecahan masalah dan berpikir kreatif Geometri SMP melalui pembelajaran berbasis masalah berbantuan Cabri Geometry II. Tesis M.Pd tidak dipublikasikan. Universitas Pendidikan Indonesia.

Munandar, U. (2009). Pengembangan kreativitas anak berbakat. Jakarta: PT Rineka Cipta.
NCTM. (2000). Principles and standards for school mathematics. Reston: The National Council of The Teacher of Mathematics.

NCTM. (2010). PISA 2009 results: what students know and can do student performance in reading, mathematics and science (volume I). Diakses pada tanggal 4 juli 2012 dari http://www.oecdilibrary.org/educati-on/pisa-2009-resultswhat-students-know-and-cando_9789264091450-en

Presiden RI. (2006). Peraturan Pemerintah RI Nomor 22, Tahun 2006, tentang Standar Isi.

Rahman. R. (2010). Pengaruh pembelajaran berbantuan Geogebra terhadap kemampuan berpikir kreatif dan selfconcept siswa. Tesis M.Pd tidak dipublikasikan. Universitas Pendidikan Indonesia.

Santrock, J.W. (2007). Remaja (11 ${ }^{\text {th }}$ ed jilid 1). (Terjemahan Benedictine Widyasinta). Jakarta: Erlangga.

Sugiyono. (2007). Memotivasi siswa belajar geometri dengan lingkaran titik sembilan. PYTHAGORAS: Jurnal Pendidikan Matematika, 3(2), 65-71.

Warsita, B. (2011). Teknologi pembelajaran: Landasan dan teorinya. Jakarta: PT Rineka Cipta. 